\title{
HUBUNGAN PENGETAHUAN DAN SIKAP KEPALA KELUARGA TENTANG FILARIASISI DENGAN MENGONSUMSI OBAT PENCEGAHAN FILARIASIS DI DESA BERANCAH WILAYAH UPT PUSKESMAS SELATBARU TAHUN 2016
}

\author{
M.Nizar Syarif Hamidi, Asmawati \\ Dosen dan Alumni FIK Universitas Pahlawan Tuanku Tambusai, Riau, Indonesia \\ nizar_hamidi@yahoo.com
}

\begin{abstract}
ABSTRAK
Jumlah penduduk di dunia terdapat 1,3 miliar yang tersebar lebih dari 83 negara memiliki resiko tertular filariasis. Kasus filariasis di Indonesia pada tahun 2009 dilaporkan sebanyak 11.914. Filariasis (penyakit kaki gajah) adalah penyakit menular menahun yang disebabkan oleh cacing filaria yang menyerang saluran dan kelenjar getah bening. Pemerintah Indonesia membuat kebijakan mengenai penanganan filariasis, yaitu dengan memutuskan mata rantai penularan filariasis dengan pemberian obat massal pencegahan filariasis (POMP F) di daerah endemis filariasis, mencegah dan membatasi kecacatan karena filariasis. Tujuan dari penelitian ini adalah untuk menganalisis hubungan antara pengetahuan dan sikap kepala keluarga tentang filariasis dengan mengonsumsi obat pencegahan filariasis. Metode penelitian menggunakan observation analitik dengan pendekatan cross sectional. Jumlah populasi $737 \mathrm{KK}$ dengan sampel sebanyak 260 responden. Adapun teknik pengambilan sampel menggunakan simple random sampling. Instrumen pengukuran pada penelitian ini yaitu kuesioner yang telah melalui uji validitas dan reliabilitas ( $r>0.444)$. Pengolahan data menggunakan analisa univariat untuk melihat distribusi frekuensi pada tiap variabel dan analisa bivariat menggunakan uji chi-square. Hasil analisa univariat didapatkan umur terbanyak dewasa awal, pendidikan terbanyak SMA, dengan frekuensi minum obat terbanyak. Pengetahuan dan sikap terhadap mengonsumsi obat filariasis didapatkan pengetahuan baik sebanyak 197 responden (75,8 \%), dan sikap positif terhadap mengonsumsi obat filariasis sebanyak 132 responden $(50,8 \%)$. Hasil penelitian menunjukkan bahwa ada hubungan yang bermakna antara tingkat pengetahuan dan sikap keluarga tentang filariasis dengan mengonsumsi obat pencegahan filariasis (Pvalue $=0,000$ ). Berdasarkan hasil penelitian ini, disarankan kepada semua pihak baik Dinas Kesehatan, Puskesmas dan masyarakat saling bekerjasama dalam memutuskan mata rantai penularan penyakit filariasis dengan berpartisipasi mengonsumsi obat filariasis.
\end{abstract}

Daftar Bacaan : : 42 ( 2004 - 2015 )

Kata kunci : Filariasis, Mengonsumsi Obat Filariasis, Pengetahuan, Sikap 


\section{PENDAHULUAN}

\section{A. Latar Belakang}

Filariasis (penyakit kaki gajah) adalah penyakit menular menahun yang disebabkan oleh cacing filaria yang menyerang saluran dan kelenjar getah bening. Penyakit ini dapat merusak system limfe, menimbulkan pembengkakan pada tangan, kaki, glandula mamae dan scrotum, menimbulkan cacat seumur hidup serta stigma sosial bagi penderita dan keluarganya. Secara tidak langsung, penyakit yang ditularkan berbagai jenis nyamuk ini dapat berdampak pada penurunan produktifitas kerja penderita, beban keluarga (Kemenkes RI, 2015).

Faktor penyebab terjadinya filariasis pada seseorang sangat kompleks, diantaranya adalah cacing sebagai agen, manusia sebagai hospes, dan nyamuk dewasa sebagai vektor. Ada tiga spesies cacing penyebab filariasis di Indonesia, yaitu Wuchereria bancrofti, Brugia malayi,dan Brugia timori. Semua spesies tersebut terdapat di Indonesia, namun lebih dari $70 \%$ kasus filariasis di Indonesia disebabkan oleh Brugia malayi (Kemenkes RI, 2010).

Data World Health Organization (WHO) tahun 2004 dalam Kemenkes RI (2010) menunjukkkan bahwa terdapat 1,3 miliar penduduk dunia yang tinggal di lebih dari 83 negara, beresiko untuk tertular filariasis, dan sebagian besar berada di Asia Tenggara. Lebih dari 120 juta orang diperkirakan sudah terinfeksi filariasis, dan sekitar $36 \%$ diantaranya sudah menunjukkan gejala klinis berupa pembengkakan anggota tubuh di kaki atau lengan
(Lymphoedema) atau anggota tubuh lainnya. Kasus filariasis di Indonesia pada tahun 2009 dilaporkan sebanyak 11.914 kasus. Tiga provinsi dengan jumlah kasus filariasis terbanyak adalah Nanggroe Aceh Darussalam (2.359 orang), Nusa Tenggara Timur (1.730 orang) dan Papua (1.158 orang). Adapun Provinsi Riau berada di urutan ke lima dengan jumlah kasus 532 orang (Kemenkes RI, 2010).

Diprovinsi Riau, Inhil merupakan kabupaten kasus filariasis terbanyak dengan 73 orang, diikuti Inhu 44 orang, Rohil 40 orang, Siak dan Meranti dengan 20 orang, Pelalawan 17 Orang, Dumai 12 orang. Kuansing 11 orang, Rohul 6 orang, Bengkalis 4 orang, dan yang paling sedikit kasus filariasis yaitu Pekanbaru 3 orang (Dinkes Riau,2015). Kabupaten Bengkalis merupakan daerah endemis penyakit filariasis, dari data yang ada kasus kronis filariasis masih terdapat di empat Kecamatan dengan jumlah kasus elephantiasis (kaki gajah) yang dilaporkan sebanyak empat kasus yang ditemui di empat desa. Secara umum Mf-rate di Kabupaten Bengkalis sampai dengan tahun 2015, masih di atas (>1\%). Di wilayah kerja puskesmas Kecamatan Bantan terdapat satu kasus penderita filariasis (Dinas Kesehatan Kabupaten Bengkalis,2015).

Mengikuti program yang telah dicanangkan WHO dalam pemberantasan filariasis, pemerintah Indonesia membuat kebijakan dalam peraturan pemerintah nomor 94 tahun 2014 tentang penanganan filariasis, yaitu dengan memutuskan rantai penularan dengan pemberian 
obat massal pencegahan filariasis (POMP filariasis) di daerah endemis, mencegah dan membatasi kecacatan karena filariasis. Pemerintah juga melakukan upaya promosi kesehatan terkait pengetahuan terhadap filariais (Kemenkes Ri, 2015) Presentase masyarakat Riau dalam minum obat filariasis yaitu Kabupaten Kampar sebesar 88,27\%, Indragiri Hulu sebesar $\quad 89,4 \%$,Inhil $78,41 \%$, Bengkalis $90,6 \%$, Siak $86,74 \%$, Rokan Hilir 91,3\%, Kepulauan Meranti 93,6\%, Kuansing 93,25\%, (Dinkes Provinsi Riau 2015)

Berdasarkan data yang didapat dari UPT Puskesmas Selat Baru (2015) yang terdiri dari 14 Desa adapun jumlah presentase masyarakat minum obat dari Desa tertinggi Selat Baru 97,60\%, Desa Teluk Papal 96,89\%, Desa Bantan Timur 96,39 \%, Desa Ulu Pulau 95,46 \%, Desa Mentayan 94,51\%, Desa Pasiran 93,99\%, Desa Jangkang 93,94\%, Desa Bantan Tengah 93,45\%, Desa Bantan Sari 93,24\%, Desa Deluk 92,54\%, Desa Resam Lapis 91,49\%, Desa Berancah 89,75\%, Desa Bantan Air 84,09\%, Desa Bantan Tua 88,95\%. Dari hasil persentase diatas masih dikatakan kurang baik pada tingkat mengonsumsi obat pencegahan filariasis kepala keluarga di Wilayah UPT Puskesmas Selat Baru dengan masih terdapat 1 kasus penderita filariasis. Meskipun cakupan tersebut sudah tercapai sesuai cakupan sebesar 60 - $100 \%$ namun jika terdapat 1 kasus diwilayah tersebut merupakan endemis filariasis maka hal tersebut menjadi kasus luar biasa.

Kepatuhan kepala keluarga dalam mengonsumsi obat filariasis dipengaruhi oleh pengetahuan, sikap, serta praktek yang mereka lakukan terkait dengan POMP (Endang, 2014). Pengetahuan yang tinggi akan mempengaruhi kepatuhan minum obat filariasis karena tingginya kesadaran yang timbul karena memiliki pengetahuan yang tinggi. Selain mempunyai pengetahuan yang tinggi juga akan mempengaruhi sikap kepala keluarga terhadap kepatuhan dalam mengonsumsi obat filariasis. Kepala keluarga yang tidak mengetahui efek samping dari obat filariasis tidak akan minum obat selanjutnya, dikarenakan efek samping yang timbul setelah minum obat filariasis. Kepala keluarga beranggapan bahwa efek yang timbul akan membahayakan sehingga membuat kepala keluarga tidak mengonsumsi obat yang selanjutnya (Lusi 2013).

Dalam pengobatan filariasis, tercapainya target pengobatan filariasis dipengaruhi beberapa faktor, diantaranya pengetahuan, sikap, lingkungan, budaya, ekonomi, dan lain-lain. Yang paling mendasari dalam kepatuhan dalam pengobatan filariasis yaitu tingkat pengetahuan kepala keluarga, dimana dengan baiknya tingkat pengetahuan kepala keluarga terhadap filariasis akan menimbulkan kesadaran yang tinggi dalam pengobatan filariasis (Lusi, 2013). Selain itu, sikap kepala keluarga juga berpengaruh terhadap pengobatan filariasis. Penurunan pencapaian pengobatan filariasis disebabkan sikap kepala keluarga yang tidak mengetahui efek samping dari obat filariasis. Efek samping setelah mengonsumsi obat filariasis yaitu, pusing, mual, muntah, mencret dan memungkinkam hingga pingsan (Gilang, 2016). 


\section{B. Perumusan Masalah}

Rumusan masalah dalam penelitian ini adalah untuk mengetahui :

1. Bagaimana pengetahuan kepala keluarga tentang filariasis dengan mengonsumsi obat pencegahan filariasis di Desa Berancah wilayah kerja UPT Puskesmas Selat Baru.?

2. Bagaimana sikap kepala keluarga tentang filariasis dengan mengonsumsi obat pencegahan filariasis di Desa Berancah wilayah kerja UPT Puskesmas Selat Baru.?

\section{Tujuan Penelitian}

\section{Tujuan Umum}

Untuk mengetahui hubungan antara pengetahuan dan sikap kepala keluarga tentang filariasis dengan mengonsumsi obat pencegahan filariasis di Desa Berancah wilayah kerja UPT Puskesmas Selat Baru.

\section{Tujuan Khusus}

a. Mengetahui distribusi frekuensi responden meliputi: Pengetahuan, sikap dan mengonsumsi obat filariasis di

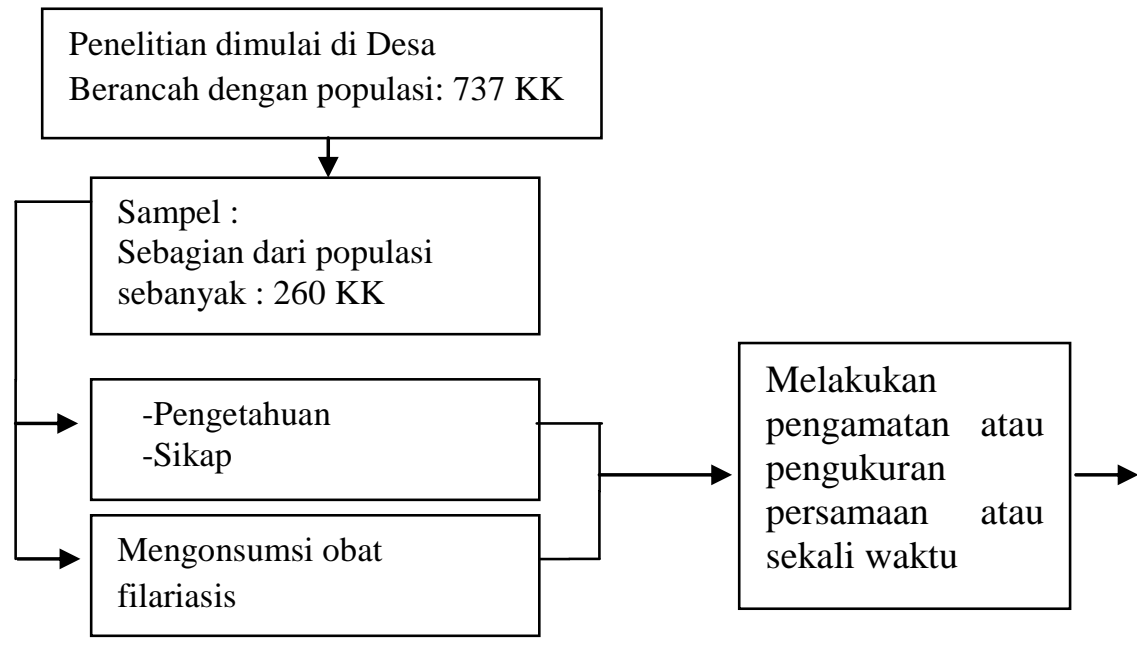

Skema 3.3 Rancangan Penelitian
Desa Berancah wilayah kerja UPT Puskesmas Selat Baru.

b. Menganalisis hubungan pengetahuan kepala keluarga tentang filariasis dengan mengonsumsi obat pencegahan filariasis di Desa Berancah wilayah kerja UPT Puskesmas Selat Baru.

c. Menganalisis hubungan sikap kepala keluarga tentang filariasis dengan mengonsumsi obat pencegahan filariasis di Desa Berancah wilayah kerja UPT Puskesmas Selat Baru.

\section{METODE PENELITIAN}

\section{A. Desain Penelitian}

\section{Rancangan Penelitian}

Penelitian ini menggunakan desain penelitian observation analitik dengan pendekatan Cross Sectional, karena pengukuran variable bebas Pengetahuan dan Sikap terhadap obat Filariasis dengan variable terikat mengonsumsi obat pencegahan Filariasis dilakukan sekali waktu pada saat yang bersamaan Notoatmojo, 2012) 


\section{Alur Penelitian}

Alur penelitian dapat dilihat pada skema sebagai berikut :

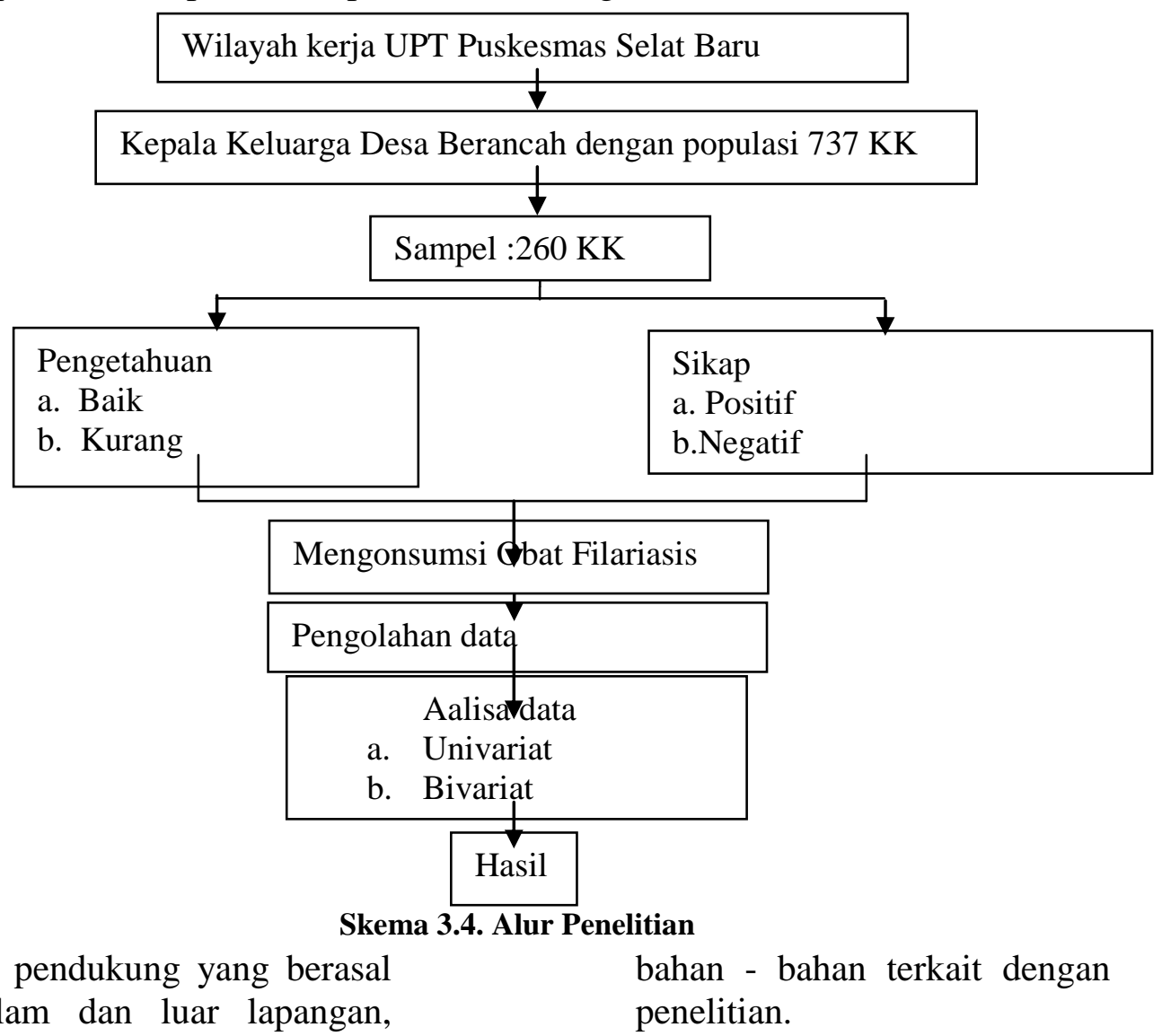

dari dalam dan luar lapangan, yaitu sebagai berikut :

1) Data primer

Pengumpulan data diperoleh langsung melalui responden yang akan diteliti dengan menggunakan kuesioner sebagai alat pengumpulan data, responden secara langsung menceklis jawaban yang telah tersedia di kuesioner.

2) Data sekunder

Diperoleh atau dikumpulkan oleh peneliti dari sumber sumber yang telah ada, yaitu data dari Puskesmas Selat Baru serta membaca atau mempelajari buku - buku teks,

\section{Variabel penelitian}

B. Lokasi dan waktu penelitian

1. Lokasi penelitian

Penelitian dilakukan di Desa Berancah Wilayah Kerja UPT Puskemas Selat Baru Kecamatan Bantan.

2. Waktu penelitian

Penelitian ini dilakukan pada tanggal 13 s/d 20 Desember tahun 2016.

\section{Populasi dan sampel}

1. Populasi penelitian

Populasi adalah keseluruhan objek yang akan diteliti dan populasi dalam penelitian ini. (Notoatmojo 2012). Populasi 
dapat bersifat terbatas dan tidak terbatas, dikatakan terbatas apabila jumlah individu atau objek dalam populasi tersebut terbatas dalam arti dapat dihitung. Sedangkan bersifat tidak terbatas dalam arti tidak dapat ditentukan jumlah individu atau objek dalam populasi tersebut (Hidayat, 2009). Populasi penelitian adalah kepala keluarga yang ada di Desa Berancah wilayah kerja UPT Puskesmas Selat Baru Kecamatan Bantan sebanyak 737 KK.

2. Sampel penelitian

Sampel dalam penelitian adalah bagian dari populasi yang dipilih dengan cara tertentu hingga dianggap dapat mewakili populasinya (Sastroasmoro, 2010).

Adapun besar jumlah sampel dalam penelitian ini adalah $260 \mathrm{KK}$.

b. Teknik Penarikan Sampel

Pemilihan sampel pada penelitian ini menggunakan teknik Simple Random Sampling yaitu pengambilan sampel dengan cara acak tanpa memperhatikan strata yang ada dalam anggota populasi. Cara ini dilakukan bila anggota populasi bila homogen.

Syarat dalam prosedur penarikan sampel ini yaitu $25 \%$ dari area atau wilayah yang diteliti (Wood \& Haber, 2006). Jumlah RT yang ada di Desa Berancah 27 RT. Penarikan sampel 7 dari 27 RT dilakukan dengan cara cabut undi. Masing-masing RT diambil sebanyak 12-13 responden.

\section{E. Alat pengumpulan data}

Metode instrumen dalam pengukuran penelitian ini melalui kuesioner yaitu pernyataan tertulis yang digunakan untuk memperoleh informasi dari responden dalam arti laporan tentang pribadinya atau hal hal yang ingin diketahui (Arikunto,2012).

Alat pengumpulan data dalam penelitian ini berupa kuesioner yang berisi tentang pertanyaan sesuai dengan variabel penelitian yaitu :

1) Pengetahuan

Kuesioner pengetahuan masyarakat tentang filariasis untuk mengetahui apakah masyarakat mengetahui terhadap filariasis terdiri dari 20 item multiple choice, dengan memberikan nilai 1 pada jawaban benar serta 0 untuk jawaban salah.

Maka tingkat pengetahuan dapat dibedakan menjadi :

a. Pengetahuan kurang, jika $<56 \%$ jawaban benar

b. Pengetahuan baik, jika $\geq 56 \%$ jawaban benar

2) Sikap

Metode penilaian sikap masyarakat menggunakan skala likert (Sugiyono 2012). Dalam pembuatan kuesioner, penelitian membuat pertanyaan sendiri dengan dasar landasan teori sikap kuesioner ini terdiri dari 4 altenatif jawaban, yaitu sangat Setuju (SS), Setuju (S), Tidak setuju (TS), Sangat Tidak Setuju (STS). Pertanyaan dibuat dua tipe yaitu favourable dan unfavourable terhadap objek metode ini penilaian adalah

a) Sifat favourable merupakan sifat positif dari pertanyaan, alternatif jawaban yang diberikan adalah :
a) Sangat Setuju (SS) bernilai 4
b) Setuju (S) bernilai 3
c) Tidak Setuju(TS) bernilai 2
d) Sangat Tidak Setuju (STS) bernilai 1 
b) Sifat unfavaurable merupakan sifat negatif dari pertanyaan, alternatif jawaban yang diberikan adalah:
a) Sangat Setuju (SS) bernilai 1
b) Setuju (S) bernilai 2
c) Tidak Setuju (TS) bernilai 3
d) SangatTidak Setuju (STS) bernilai 4

F.

\section{G. Definisi Operasional}

Definisi operasional adalah mendefenisikan variabel secara

\section{H.Pengolahan Data}

Menurut Notoatmodjo (2010), didalam pengolahan data, penilaian dilakukan dengan komputerisasi. Setelah terkumpul data kemudian diolah dengan mengikuti langkah langkah berikut :

\section{Editing}

Merupakan pengecekan isi kuesioner, memastikan isi kuesioner yang ada sudah lengkap jawabannya (di isi semua) jelas terbaca, relevan dan konsisten.

2. Coding

Sebelum dimasukkan ke komputer dilakukan proses pemberian kode pada setiap variabel yang dapat terkumpul. Pengkodean data ini didasarkan pada kategori yang telah untuk memudahkan dalam pengolahan selanjutnya.

3. Entry

Meng-entry data kuesioner dalam program komputerisasi sesuai dengan variabel penelitian.

\section{Cleaning}

Setelah semua data dimasukkan kedalam program computer, peneliti mengecek kembali apakah ada kesalahan data,sehingga data siap untuk dianalisa. operasional berdasarkan karakteristik yang diteliti, sehingga memungkinkan peneliti untuk melakukan observasi atau pengukuran secara cermat terhadap suatu objek atau fenomena. Definisi operasional ditentukan berdasarkan parameter yang dijadikan ukuran dalam penelitian, sedangkan cara pengukuran merupakan cara dimana variabel dapat diukur dan ditentukan karakteritiknya (Hidayat, 2007).

\section{Processing}

Kemudian peneliti melakukan pengolahan data melalui program computer dengan analize sesuai dengan uji statistik yang digunakan.

\section{Analisa Data}

\section{Analisis Univariat}

Analisis Univariat merupakan suatu analisis untuk mendiskripsikan karekteristik masing-masing variabel yang diteliti. Analisis ini bertujuan untuk mengetahui gambaran distribusi frekuensi responden dan proporsi dari tiap-tiap variabel yang diteliti yaitu variabel dependen dan independen yang dibuat dalam bentuk tabel distribusi frekuensi dan diinterpretasikan secara deskriptif

2. Analisis Bivariat

Analisis bivariat dilakukan terhadap dua variable yang diduga berhubungan dan berkolerasi. Analisis ini digunakan untuk menguji hipotesis dengan menentukan hubungan variable bebas dan variable terikat melalui uji statistic Chi Square. Analisis ini dilakukan untuk mengetahui antara varibel independen dengan variable dependen.Analisis yang digunakan adalah Chi Square. Jika 
Syarat uji Chi Square tidak terpenuhi baris/kolom sel digabungkan,jika tidak tetap memenuhi syarat digunakan uji lainnya yaitu Fisher Exact, dengan dasar pengambilan keputusan yaitu dengan membandingkan nilai $\mathrm{p}$ dengan nilai 0,05 sebagai berikut :

a. Jika nilai $P>0,05$, maka keputusan Ho diterima artinya tidak ada yang bermakna antara variable independen dengan variable dependen

b. Jika nilai $P \leq 0,05$, maka keputusan Ho ditolak artinya Tabel 4.2

Distribusi Frekuensi Responden Berdasarkan Karakteristik Responden di Desa Berancah Wilayah UPT Puskesmas Selat Baru Tahun 2016

\begin{tabular}{clcc}
\hline No & \multicolumn{1}{c}{ Karakteristik } & Frekuensi & Persentase (\%) \\
\hline 1. & Umur & & \\
& - Dewasa awal & $\mathbf{1 4 6}$ & $\mathbf{5 6 . 2}$ \\
& - Dewasa akhir & 94 & 36.2 \\
& - Lansia & 20 & 7.7 \\
\hline \multicolumn{2}{l}{ Total } & 260 & 100 \\
\hline 2. & Pendidikan terakhir & 32 & 12.3 \\
& - Tidak sekolah & 26 & 10.0 \\
& - SD & 63 & 24.2 \\
& - SMP & $\mathbf{8 2}$ & $\mathbf{3 5 . 5}$ \\
& - SMA & 57 & 21,9 \\
\hline & - Sarjana & 260 & 100 \\
\hline Total & Mengonsumsi obat & & \\
& - Minum & $\mathbf{1 4 3}$ & $\mathbf{5 5 . 0}$ \\
& - Tidak minum & 117 & 45.0 \\
\hline & Total & 260 & 100 \\
\hline
\end{tabular}

Sumber: Penyebaran kuesioner

Tabel 4.2 menunjukan bahwa dari 260 responden yang diteliti, sebagian responden yaitu146 $(56,2 \%)$ termasuk pada kategori dewasa awal (19-34 tahun). Berdasarkan pendidikan terakhir, $>$ dari sepertiga yaitu $82(35,5 \%)$ responden memiliki tingkat pendidikan tamat SMA dengan mengonsumsi obat filariasis sebanyak 143 orang responden $(55.0 \%)$. terdapat hubungan yang bermakna antara variabel independen dan dependen

\section{A. Analisa Univariat}

1. Karakteristik responden

Pada karakteristik responden peneliti memaparkan distribusi frekuensi dan persentasi tentang data demografi dan variabel yang diteliti. Adapun hasil analisa dapat dilihat pada uraian berikut:

\section{HASIL PENELITIAN}




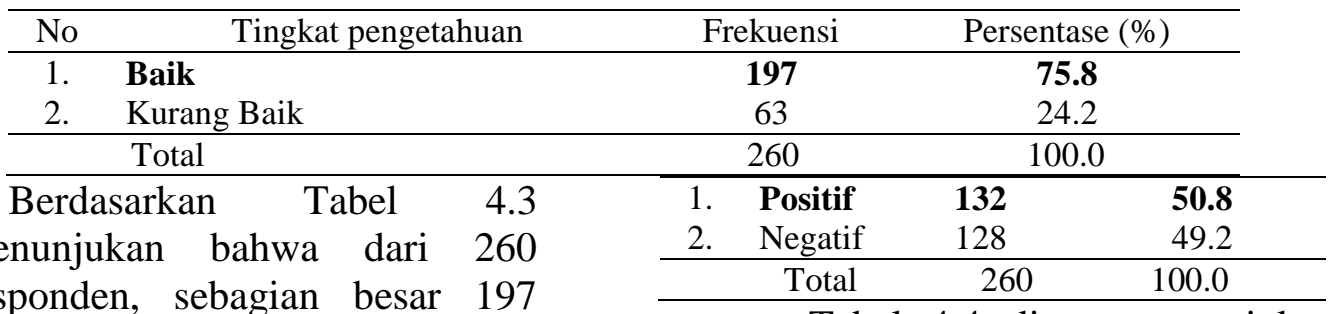

(75.8\%) responden termasuk kategori pengetahuan baik.tingkat pengetahuan sebagian besar responden yaitu dengan tingkat pengetahuan baik berjumlah 197 orang responden $(75.8 \%)$ dan responden yang paling sedikit dengan tingkat pengetahuan kurang baik berjumlah 63 orang responden $(24.2 \%)$.

3. Sikap kepala keluarga tentang mengonsumsi obat filariasis

Tabel 4.4

Distribusi Frekuensi Responden berdasarkan Sikap tentang Mengonsumsi Obat Filariasis di Desa Berancah Wilayah UPT Puskesmas Selat Baru tahun 2016

Tabel 4.4 diatas menunjukan bahwa sebagian besar sikap responden yaitu positif yang berjumlah 132 orang responden $(50.8 \%)$ dan memiliki sikap negatif sebanyak 128 orang reponden (49.2\%).

\section{B. Analisa Bivariat}

\section{Hubungan pengetahuan kepala keluarga tentang filariasis dengan mengonsumsi obat filariasis}

Tabel 4.5

Hubungan Pengetahuan Kepala keluarga tentang Filariasis dengan Mengonsumsi Obat Filariasis di Desa Berancah Wilayah UPT Puskesmas Selat Baru tahun 2016

\begin{tabular}{|c|c|c|c|c|c|c|c|c|c|}
\hline \multirow[t]{3}{*}{ No } & Sikap & Frekuensi & Perse & se $(\%$ & & & & & \\
\hline & \multirow{3}{*}{ Pengetahuan } & \multicolumn{4}{|c|}{ Mengonsumsi Obat Filariasis } & \multirow{2}{*}{\multicolumn{2}{|c|}{ Total }} & \multirow{3}{*}{ P Value } & \multirow{3}{*}{ POR } \\
\hline & & \multicolumn{2}{|c|}{ Mengonsumsi } & \multicolumn{2}{|c|}{$\begin{array}{c}\text { Tidak } \\
\text { Mengonsumsi }\end{array}$} & & & & \\
\hline & & $\mathrm{n}$ & $\%$ & $\mathrm{n}$ & $\%$ & $\mathrm{n}$ & $\%$ & & \\
\hline & Baik & 132 & 67,0 & 65 & 33,0 & 197 & 100 & \multirow{2}{*}{0.000} & \multirow{2}{*}{9,600} \\
\hline & Kurang Baik & 11 & 17,5 & 52 & 82,5 & 63 & 100 & & \\
\hline & Total & 143 & & 117 & & 260 & & & \\
\hline
\end{tabular}

Sumber : Penyebaran kuesioner

Dari tabel 4.5 diatas didapatkan 197 responden berpengetahuan baik tentang mengonsumsi obat filariasis, namun terdapat 65 orang $(33,0 \%)$ responden yang tidak mengonsumsi obat filariasis. Sedangkan dari 63 responden yang berpengetahuan kurang baik terdapat 11 responden $(17,5 \%)$ yang mengonsumsi obat filariasis. Hasil uji statistik diperoleh nilai $P$ value $\leq 0,05 \quad(P$ value $=0.000)$ atau Ho ditolak, artinya terdapat hubungan yang bermakna antara pengetahuan kepala keluarga tentang filariasis dengan mengonsumsi obat filariasis.

2. Hubungan sikap kepala keluarga tentang filariasis dengan mengonsumsi obat filariasis

Tabel 4.6

Hubungan Sikap kepala keluarga tentang Filariasis dengan Mengonsumsi Obat Filariasis di Desa Berancah Wilayah UPT 
Puskesmas Selat Baru Tahun 2016

\begin{tabular}{|c|c|c|c|c|c|c|c|c|}
\hline \multirow{3}{*}{ Sikap } & \multicolumn{4}{|c|}{ mengonsumsi Obat Filariasis } & \multirow{2}{*}{\multicolumn{2}{|c|}{ Total }} & \multirow{3}{*}{ P Value } & \multirow{3}{*}{ POR } \\
\hline & \multicolumn{2}{|c|}{ Mengonsumsi } & \multicolumn{2}{|c|}{$\begin{array}{c}\text { Tidak } \\
\text { Mengonsumsi }\end{array}$} & & & & \\
\hline & $\mathrm{n}$ & $\%$ & $\mathrm{n}$ & $\%$ & $\mathrm{n}$ & $\%$ & & \\
\hline Positif & 94 & 71,2 & 38 & 28,8 & 132 & 100 & ח & 0251 \\
\hline Negatif & 49 & 38,3 & 79 & 61,7 & 128 & 100 & 0.000 & 0,251 \\
\hline Total & 143 & & 117 & & 260 & & & \\
\hline
\end{tabular}

Sumber : Penyebaran kuesioner

Pada tabel 4.6 diatas diperoleh 132 responden yang bersikap positif tentang mengonsumsi obat filariasis, namun masih terdapat 38 responden $(28,8 \%)$ yang tidak mengonsumsi obat filariasis. Sedangkan dari 128 responden yang bersikap negative terdapat 49 responden $(38,3 \%)$ yang mengonsumsi obat filariasis. Adapun hasil uji statistik diperoleh nilai $P$ value $\leq 0,05(P$ value $=0.000$ ) atau Ho ditolak, maka terdapat hubungan yang bermakna antara sikap kepala keluarga tentang filariasis dengan mengonsumsi obat filariasis.

\section{PEMBAHASAN}

Menurut hasil yang telah diuraikan sebelumnya, maka pada bab ini akan dibahas secara sistematis yaitu hasil penelitian hubungan pengetahuan dan sikap kepala keluarga tentang filariasis dengan mengonsumsi obat filariasis di Desa Berancah UPT Puskesmas Selat Baru dengan menggunakan analisa univariat dan bivariat.

\section{A. Analisa Univariat}

\section{Karakteristik Responden}

Hasil penelitian ini menunjukkan karakteristik responden berdasarkan kategori umur didapatkan usia responden terbanyak berada pada kategori dewasa awal (19-34 tahun) dengan jumlah 146 orang responden $(56.2 \%)$. Berdasarkan pendidikan terakhir responden terbanyak dengan pendidikan terakhir SMA berjumlah 82 orang responden $(35.5 \%)$ dengan konsumsi obat filariasis sebanyak 143 orang responden $(55.0 \%)$.

Hal ini menunjukan bahwa sebagian besar kepala keluarga desa Berancah adalah berada pada usia produktif. Semakin cukup umur, tingkat kematangan dan kekuatan seseorang akan lebih matang dalam berfikir dan bekerja.

Penelitian ini juga memperoleh hasil bahwa pendidikan tertinggi responden adalah perguruan tinggi, namun responden dengan tingkat pendidikan terbanyak adalah SMA. Menurut Notoatmodjo (2007), semakin tinggi tingkat pendidikan seseorang maka akan semakin mudah untuk menerima informasi sehingga semakin banyak pula pengetahuan yang dapat dimiliki. Sebaliknya, pendidikan yang rendah akan menghambat perkembangan sikap seseorang terhadap nilai baru yang dikenal, karena pendidikan formal yang dimiliki seseorang akan mempengaruhi pengetahuan dan 
kemampuan seseorang dalam memahami sesuatu.

2. Tingkat Pengetahuan Kepala keluarga tentang Mengonsumsi Obat Filariasis

Hasil penelitian mengenai tingkat pengetahuan kepala keluarga tentang mengonsumsi obat filariasis didapatkan bahwa sebagian besar kepala keluarga memiliki tingkat pengetahuan baik yaitu sebanyak 197 orang $(75,8 \%)$ pengetahuan baik berjumlah 197 orang responden $(75.8 \%)$ dan responden yang paling sedikit dengan tingkat pengetahuan kurang baik berjumlah 63 orang responden (24.2\%).

Menurut Mubarak, Khairul, Nurul, dan Supriadi (2007), ada beberapa faktor yang dapat mempengaruhi pengetahuan seseorang, diantaranya adalah informasi dan pengalaman. Kemudahan untuk memperoleh informasi dapat membantu mempercepat seseorang untuk memperoleh pengetahuan yang baru, sedangkan pengalaman adalah suatu kejadian yang pernah dialami seseorang untuk berinteraksi dengan lingkungannya. Ada kecenderungan pengalaman yang kurang baik seseorang akan berusaha untuk melupakan, namun jika pengalaman terhadap objek tersebut menyenangkan maka secara psikologis akan timbul kesan yang sangat mendalam dan membekas dalam emosi kejiwaannya, dan akhirnya dapat pula membentuk sikap positif dalam kehidupannya. Berdasarkan teori tersebut, peneliti mengambil kesimpulan bahwa kepala keluarga yang pernah bertemu atau melihat langsung penderita filariasis tentunya akan termotifasi untuk menghindari penyakit dan berusaha mencari tahu informasi mengenal penyakit tersebut.

Menurut Notoatmodjo (2007), faktor yang mempengaruhi tingkat pengetahuan yaitu faktor internal dan faktor eksternal. Faktor internal terdiri dari pendidikan, motivasi dan persepsi. Adapun faktor eksternalnya terdiri dari informasi, sosial budaya dan lingkungan. Seseorang mempunyai pengetahuan tentang suatu hal tidak hanya melalui jenjang pendidikan saja, tetapi didukung oleh terpapar informasi dari media massa yang ada seperti televisi, radio, koran, majalah dan sebagainya. Selain itu, motivasi juga mempengaruhi seseorang untuk berusaha ingin tahu terhadap sesuatu. Semakin tinggi rasa ingin tahu semakin tinggi pula motivasi untuk mencari informasi tentang hal tersebut. Teori ini sesuai dengan hasil wawancara peneliti dengan kepala keluarga pada saat penelitian yang mengatakan bahwa informasi yang mereka dapatkan sebagian besar diperoleh dari petugas kesehatan dan salah satu motivasi kepala keluarga mencari informasi tentang mengonsumsi obat filariasis. Petugas kesehatan merupakan orang yang dipercaya oleh kepala keluarga dalam hal ilmu kesehatan sehingga keberadaannya sangat diperlukan ketika ada program yang harus dijalani kepala keluarga. Petugas kesehatan sebelum memberikan pengobatan massal, menjelang pengobatan kurang dari 1 bulan sebaiknya diadakan sosialisasi 
kepada kepala keluarga untuk meningkatkan pengetahuan tentang penyakit filariasis. Sehingga kepala keluarga melaksanakan pengobatan dan menyikapi dengan benar apabila terjadi reaksi pengobatan dengan benar.

3. Sikap Kepala keluarga tentang Konsumsi Obat Filariasis

Hasil penelitian mengenai sikap kepala keluarga tentang mengonsumsi obat filariasis didapatkan bahwa sebagian besar kepala keluarga memiliki sebagian besar sikap responden positif yang berjumlah 132 orang responden $(50.8 \%)$ dan memiliki sikap negatif sebanyak 128 orang reponden $(49.2 \%)$.

Hal ini berarti sebagian besar kepala keluarga memiliki persepsi dan pandangan yang positif terhadap kepatuhan minum obat filariasis. Menurut Notoatmodjo (2007), terbentuknya perilaku baru yaitu sikap, dimulai dari domain kognitif dalam arti subjek atau individu mengetahui terlebih dahulu terhadap stimulus berupa materi atau objek diluarnya, yang menimbulkan pengetahuan baru pada individu sehingga terbentuk respon batin yang tampak dalam sikap individu terhadap objek yang diketahuinya tersebut. Namun, dalam kenyataan stimulus yang diterima oleh subjek tidak dapat langsung menimbulkan sikap terhadap stimulus yang ada. Pembentukan sikap dipengaruhi beberapa faktor, yaitu pengalaman pribadi, kebudayaan, orang lain yang dianggap penting, media massa, institusi atau lembaga pendidikan dan lembaga agama, faktor emosi dalam diri individu (Azwar, 2013). Berdasarkan hasil wawancara peneliti dengan masyarakat pada saat penelitian, faktor yang paling mempengaruhi sikap kepala keluarga dalam penelitian ini adalah pengalaman pribadi masyarakat yang pernah menyaksikan secara langsung tentang keadaan fisik penderita filariasis. Pengalaman tersebut membuat kepala keluarga memiliki sikap yang positif untuk mengonsumsi obat filariasis.

\section{B. Analisa Bivariat}

1. Hubungan Pengetahuan Kepala Keluarga Tentang Filariasis dengan Mengonsumsi Obat Filariasis

Hasil analisa statistik didapatkan 197 responden berpengetahuan baik tentang mengonsumsi obat filariasis, namun terdapat 65 orang $(33,0 \%)$ responden yang tidak mengkonsumsi obat filariasis. Sedangkan dari 63 responden yang berpengetahuan kurang terdapat 11 responden $(17,5 \%)$ yang mengonsumsi obat filariasis. Hasil uji statistik diperoleh nilai $\mathrm{P}$ value $\leq 0,05 \quad(P$ value $=0.000)$ atau Ho ditolak, artinya terdapat hubungan yang bermakna antara pengetahuan kepala keluarga tentang filariasis dengan mengonsumsi obat filariasis.

Berdasarkan uraian hasil penelitian diatas,peneliti berasumsi bahwa kepala keluarga yang baik pengetahuannya cenderung memberikan obat filariasis. Akan tetapi pada penelitian ini masih terdapat 65 orang $(33,0 \%)$ yang tidak mengonsumsi obat filariasis, Kepala keluarga kurang mengetahui pentingnya dalam mengonsumsi obat filariasis, juga alasan kepala keluarga tidak 
mengonsumsi obat filariasis dikarenakan efek samping obat tersebut. Kepala keluarga mengeluh setelah minum obat akan merasakan mual, muntah, bahkan sampai demam, sehingga kepala keluarga takut akan meminum obat filariasis yang selanjutnya.sedangkan pada tingkat pengetahuan kurang terdapat 11 orang $(17,5 \%)$ yang mengkonsumsi obat filariasis. Hal ini disebabkan oleh keterbatasan pengetahuan kepala keluarga disebabkan kurangnya sosialisasi tentang konsumsi obat filariasis kepada kepala keluarga.

Hasil penelitian ini didukung oleh penelitian yang dilakukan Gilang (2015) dengan judul" hubungan pengetahuan dan sikap tentang pencegahan filariasis dengan praktek minum obat dalam program pemberian obat masal pencegahan (pomp) filariasis kelurahan kuripan kertoharjo kota pekalongan 2015" dengan $70 \quad$ responden dipadapatkan 50 respoden $(71,4)$ dengan pendidikan baik dengan 44 orang responden $(80 \%)$ yang meminum POMP. Hasil uji statistic didapatkan hasil $p$ value $=$ $0,007<\alpha=0.05$ sehingga terdapat hubungan pengetahuan tentang pencegahan filariasis dengan praktek minum obat dalam program pemberian obat massal pencegahan (pomp).

Penelitian ini juga sejalan dengan penelitian Purnomo (2013) dengan judul "Pengaruh faktor pengetahuan dan petugas kesehatan terhadap konsumsi minum obat kaki gajah (filariasis) di Kelurahan Bligo Kabupaten Pekalongan" yang dilakukan terhadap 94 orang responden dan didapatkan 44 orang responden $(46,8 \%)$ memiliki pengetahuan baik dan mengkonsumsi obat filariasis, berdasarkan hasil uji statistik didapatkan $p$ value = $0,001<\alpha=0.05$ sehingga dapat disipulkan terdapat pengaruh pengetahuan masyarakat terhadap konsumsi obat filariasis.

Menurut Mubarak, Khoirul, Nurul, dan Supriadi (2007), ada beberapa faktor yang dapat mempengaruhi pengetahuan seseorang, diantaranya adalah informasi dan pengalaman. Kemudahan untuk memperoleh suatu informasi dapat membantu mempercepat seseorang untuk memperoleh pengetahuan yang baru, sedangkan pengalaman adalah suatu kejadian yang pernah dialami seseorang untuk berinteraksi dengan lingkungannya. Ada kecenderungan pengalaman yang kurang baik seseorang akan berusaha untuk melupakan, namun jika pengalaman terhadap objek tersebut menyenangkan maka secara psikologis akan timbul kesan yang sangat mendalam dan membekas dalam emosi kejiwaannya, dan akhirnya dapat pula membentuk sikap positif dalam kehidupannya dan begitu pula sebaliknya.

Menurut Notoatmodjo (2007), motivasi juga mempengaruhi seseorang untuk berusaha ingin tahu terhadap sesuatu. Semakin tinggi rasa ingin tahu semakin tinggi pula motivasi untuk mencari informasi tentang hal tersebut. Pengetahuan merupakan modal yang sangat penting untuk terbentuknya tindakan seseorang. Hal ini sejalan dengan teori yang dikemukakan oleh Rogers dalam 
Notoatmodjo (2007), bahwa perilaku yang didasari oleh pengetahuan, kesadaran dan sikap yang positif akan lebih langgeng (long lasting) dari pada perilaku yang tidak didasari dengan pengetahuan, kesadaran dan sikap. Hal ini sesuai dengan hasil penelitian yang menunjukkan bahwa sebagian besar masyarakat memiliki tingkat pengetahuan yang tinggi tentang konsumsi obat filariasis.

Fitriani (2011), juga mengatakan bahwa pengetahuan merupakan hasil tahu, dan ini terjadi setelah seseorang melakukan pengindraan terhadap suatu objek tertentu. Pengindraan terjadi melalui panca indera manusia, yakni indera penglihatan, pendengaran, penciuman, rasa dan raba. Sebagian besar pengetahuan diperoleh melalui mata dan telinga. Pengetahuan atau kognitif merupakan domain yang sangat penting dalam membentuk tindakan seseorang (over behavior). Perilaku yang didasari pengetahuan umumnya bersifat langgeng (Sunaryo, 2004).

2. Hubungan antara Sikap Kepala Keluarga tentang Filariasis dengan Mengonsumsi Obat Filariasis

Hasil penelitian mengenai sikap kepala keluaraga tentang filariasis diperoleh 132 responden yang bersikap positif tentang mengonsumsi obat filariasis, namun masih terdapat 38 responden $(28,8 \%)$ yang tidak mengonsumsi obat filariasis. Sedangkan dari 128 responden yang bersikap negative terdapat 49 responden (38,3\%) yang mengonsumsi obat filariasis.
Adapun hasil uji statistik diperoleh nilai $P$ value $\leq 0,05$ (P value $=0.000$ )

Berdasarkan uraian hasil diatas, peneliti berasumsi bahwa sikap positif mempengaruhi kepala keluarga mengonsumsi obat filariasis. Tetapi dalam penelitian ini masih terdapat kepala keluarga dengan sikap positif yang tidak mengonsumsi obat filariasis sebanyak 38 responden (28,8\%). Hal ini disebabkan karena kurangnya pengalaman kepala keluarga melihat kejadian filariasis, sehingga masih terdapat kepala keluarga yang masih menganggap filariasis merupakan penyakit yang tidak berbahaya. Sedangkan dari 128 responden yang bersikap negatif terdapat 49 responden yang mengkonsumsi obat filariasis hal ini disebabkan oleh adanya kepala keluarga mengetahui akan bahaya penyakit filariasis tersebut.

Hasil penelitian ini didukung oleh penelitian yang dilakukan Agustianingsih (2013) dengan judul" Faktor-faktor yang berhubungan dengan praktik pencegahan filariasis di kelurahan kertoharjo" dengan 72 responden dipadapatkan 41 respoden dengan sikap baik dan 31 orang responden yang memiliki siap rendah. Hasil uji statistik didapatkan hasil $p$ value $=0,000 \leq$ $\alpha=0.05$ sehingga terdapat hubungan sikap dengan praktik pencegahan filariasis.

Sebagian besar kepala keluarga memiliki persepsi dan pandangan yang positif terhadap penyakit filariasis dan pencegahannya. Menurut Notoatmodjo (2007), terbentuknya perilaku baru yaitu 
sikap, dimulai dari domain kognitif dalam arti subjek atau individu mengetahui terlebih dahulu terhadap stimulus berupa materi atau objek diluarnya, yang menimbulkan pengetahuan baru pada individu sehingga terbentuk respon batin yang tampak dalam sikap individu terhadap objek yang diketahuinya tersebut. Namun, dalam kenyataan stimulus yang diterima oleh subjek tidak dapat langsung menimbulkan sikap terhadap stimulus yang ada. Pembentukan sikap dipengaruhi beberapa faktor, yaitu pengalaman pribadi, kebudayaan, orang lain yang dianggap penting, media massa, institusi atau lembaga pendidikan dan lembaga agama, faktor emosi dalam diri individu (Azwar, 2013).

Pendidikan merupakan faktor yang mempengaruhi status kesehatan, tingkat pengetahuan, sikap dan perilaku hidup sehat seseorang. Apabila seseorang dengan tingkat pendidikn tinggi akan memiliki sikap yang baik yang dapat mempengaruhi perilakunya untuk hidup sehat (Widani, 2010).

\section{DAFTAR PUSTAKA}

Agustiantiningsih, D. (2013). Faktorfaktor yang berhubungan dengan praktik pencegahan filariasis di Kelurahan Kertoharjo. Diperoleh tanggal 30 Oktober 2016 http:// journal.unnes.ac.id/artikel_nju/ke mas/2821

Arikunto, S. (2012). Prosedur penelitian: suatu pendekatan praktek. Rineka Cipta. Jakarta.

A Wawan dan Dewi M. (2010). Teori \& pengukuran pengetahuan, sikap dan perilaku manusia. Nuha Medika: Yogyakarta.

Azwar, S. (2013). Sikap manusia: Teori dan pengukurannya. Yogyakarta: Pustaka Belajar.

Dewi, K., \&Zalih, M. (2014).Hubungan pengetahuan, sikap dengan praktik masyarakat dalam upaya pencegahan penyakit filariasis di RW 11 Kelurahan Jenggot Kota Pekalongan. Sekolah Tinggi Ilmu Kesehatan Muhammadiyah Pekajangan. Diperoleh tanggal 29 Oktober 2016

Dikes Porvinsi Riau. (2015). Data statistik kejadian filariasis dan pengobatan filariasis.

Dinkes Kabupaten Bengkalis. (2015). Data statistik pengobatan filariasis di bengkalis.

Fitriani, S. (2011). Promosi Kesehatan. Yogyakarta: Graha Ilmu.

Gilang, M, R A. (2015). Hubungan pengetahuan dan sikap tentang pencegahan filariasis dengan praktek minum obat dalam program pemberian obat masal pencegahan (pomp) filariasis kelurahan kuripan kertoharjo kota pekalongan 2015. Skripsi. Diperoleh tanggal 30 November 2016

Hastono, S.P. (2007). Analisa data kesehatan. Jakarta: FKM-UI.

Hidayat, A. A. (2009). Metode Penelitian Keperawatan dan Tekhnik Analisis Data. Jakarta:. Salemba Medika

Hidayat. (2007).Metodologi penelitian. Jakarta: Pustaka pelajar.

Irianto, K. (2013). Parasitologi medis. Bandung: Alfabeta

Kemenkes RI, (2015). Petunjuk teknis penyelengaraan bulan eliminasi penyakit kaki gajah. Direktorat Penanggulangan Penyakit Bersumber Binatang, Jakarta 
Kemenkes RI. (2010). Epidemiologi filariasisi di Indonesia. Vol . Jakarta

Kemenkes RI. (2015).Peraturan menteri kesehatan republik Indonesia nomor 94 tahun 2014 tentang penanggulangan filariasis.

Lusi I, dkk. (2013). Hubungan Antara Tingkat Pengetahuan dan Sikap Masyarakat tentang Penyakit Filariasis dengan Tindakan Masyarakat dalam Pencegahan Filariasis. Diperoleh tanggal 30 Oktober 2016.

Mubarak, W. I., Nurul C., Khairul R., \& Supriadi. (2007). Promoi kesehatan. Ed.2. Yogyakarta: Graha Ilmu

Notoatmodjo, S. (2005). Metodologi penelitian kesehatan. Jakarta: Rineka Cipta.

Notoatmodjo, S. (2005). Promosi kesehatan teori dan Aplikasi. Jakarta: Rineka Cipta.

Notoatmodjo, S. (2007). Promosi kesehatan dan ilmu perilaku. Jakarta: Rineka Cipta.

Notoatmodjo, S. (2010). Metodologi penelitian kesehatan. Jakarta: Rineka Cipta.

Notoatmodjo, S. (2012). Metodologi penelitian kesehatan. Jakarta: Rineka Cipta.

Notoatmodjo, S. (2012). Promosi kesehatan dan perilaku kesehatan. Jakarta: Rineka Cipta.

Nursalam. (2009). Konsep dan penerapan metodologi penelitian ilmu keperawatan. Jakarta: Salemba Medika.

Purnomo, I. (2013). Pengaruh faktor pengetahuan dan petugas kesehatan terhadap konsumsi minum obat kaki gajah (filariasis) di Kelurahan Bligo Kabupaten Pekalongan. Diperoleh tanggal 30 Desember 2016
Sabesan, Shanmugavelu. (2006) Delimitation of lymphatic filariasis transmission risk areas: a geo-environmental approach. filaria journal, 5: 12.

Sastroasmoro, S., \& Ismail, S. (2010). Dasar-dasar metodologi penelitian klinis. Ed 3. Jakarta: Sagung Seto

Sevilla, C. dkk. (2007). Research methods. Rex Printing Company: Quezon City.

Soetjiningsih, \& Ranuh, G. (2015). Tumbuh Kembang Anak. Jakarta: EGC

Subagyo, P. J.(2011) Metode Penelitian. Jakarta: Rineka Cipta.

Sugiyono. (2012). Metode penelitian kuantitatif kualitatif dan $r \& d$. Bandung: Alfabeta.

Sunaryo. (2004). Psikologi untuk keperawatan. Jakarta: EGC.

Supali. T. (2010), Keberhasilan program eliminasi filariasis dikabupaten alor, nusa tenggara timur. buletin jendela epidemiologi, volume 1, Juli 2010.

Sutanto, I. (2009). Buku ajar parasitologi kedokteran. Jakarta: Fakultas Kedoteran Universitas Indonesia.

WHO. (2013). Lymphatic filariasis: a handbook of practical entomology for national lymphatic filariasis elimination programmes. Preparation of this document was supported by the Department for International Development of the Government of the United Kingdom of Great Britain and Northern Ireland.

Widani. (2010). Pengantar belajar dalam pendidikan. Jakarta: Graha Ilmu.

Widodo, H. (2013). Parasitologi kedokteran. Yogyakarta: DMEDIKA (Anggota IKAPI). 
Widoyono. (2008). Penyakit tropis epidemiologi, penularan, pencegahan dan pemberantasanya. Jakarta: Erlangga.

Widoyono. (2011). Penyakit tropis epidemiologi, penularan, pencegahan \& pemberantasannya. Ed II. Jakarta: Erlangga

Wood, G. L \& Haber, J. (2006). Nursing research: Methods and critical appraisal for evidencebased practice: Philadelphia: Mosby Elsevier.

Zulkoni A. (2011), parasitologi untuk keperawatan, kesehatan masyarakat, teknik lingkungan, Yogyakarta: Nuha Medika, 